\title{
World Englishes from a Holistic View and Considerations on English Education in Vietnam
}

\author{
Tran Thi Hao \\ Languages Department \\ Vinh University \\ Vietnam \\ haott@vinhuni.edu.vn
}

\author{
Ngo Dinh Phuong \\ Languages Department \\ Vinh University \\ Vietnam \\ phuongnd@vinhuni.edu.vn
}

\begin{abstract}
The development of English as the mutual language among of ASEAN context since 2008 and the formation of ASEAN Economic Community since 2015 have set milestones in the social and educational development of each country of the organisation. In English education in Vietnam, understanding the diversity of Englishes in the organisation has become an important task. This article aims to present a holistic view of World Englishes (WE) in research generally and in relation to English education in Vietnam, particularly by illustrating the Vietnamese English teachers' perceptions of WE in the Vietnamese teaching context. The data were collected via an online questionnaire using a snowball sampling method from seventy-six respondents who are English lecturers from twenty-six universities or colleges in Vietnam and via focus group interviews with five participants who were doing Master Degree in Applied Linguistics at an Australian university. The article delineates the findings of the Vietnamese English teachers' perceptions towards WE and their experiences in introducing WE in their teaching context. Discussion of English education in Vietnam, including issues in English teaching, English teachers' development and considerations of the policy context is also be presented.
\end{abstract}

Keywords-World Englishes, English education, teachers, Vietnam

\section{INTRODUCTION}

Understanding varieties of English, or World Englishes (WE), is considered a crucial task in language teaching and learning to prepare English users for effective and intelligible communication [1][3][31]. Specifically, the adoption in 2008 of English as a medium for communication among ASEAN members[17] and the formation of ASEAN Economic Community in 2015 are milestones in the social and educational development of each member country. Communication in English is thus not just among Vietnamese native speakers but also among other nationalities within region and ASEAN. Therefore, understanding of Englishes from other countries is important in line with the recognition of certain variants of English in the organisation such as Singaporean English or Cambodia English. This article thus aims to present a holistic view of WE in research generally and in the context of Vietnam particularly in relation to English education by illustrating the Vietnamese English teachers' perceptions of WE in the Vietnamese teaching context. Discussion of English education in Vietnam including issues in English teaching, English teachers' development and considerations of the policy is presented at the end of the article.

\section{Discussions on WE}

In this article, WE is discussed with respect to its development through the past three decades, combined with a review of studies conducted in this field in ASEAN context Vietnamese contexts.

\subsection{Development of WE}

The term "World Englishes" is defined variably with a range of meanings and interpretations[2]. According to [2], the three most common interpretations of WE include an umbrella label of all English varieties, new Englishes (such as Englishes in the Caribbean or Asian Englishes) and the Kachruvian pluricentric approach with three concentric circles (the norm-providing varieties of the inner circle, the norm-developing varieties of the outer circle and the normdependent varieties of the expanding circle. In accordance with the aim of the study which attempts to explore Vietnamese English teachers' perceptions of English varieties in general, within this study the term WE is employed as the first interpretation, which presents an umbrella label covering all varieties of English worldwide. 


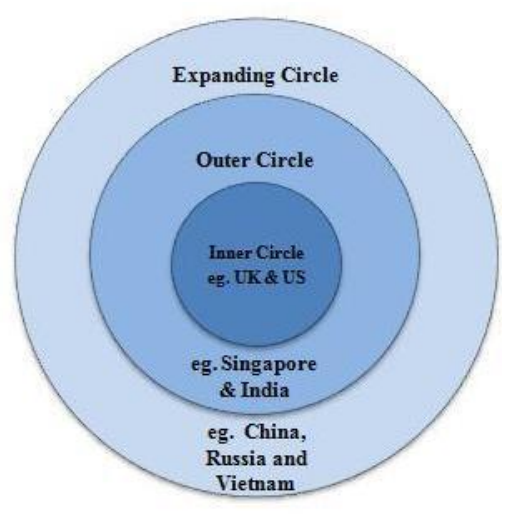

Figure 1: Kachru's1988 three concentric circles of English varieties

WE has been in the focal discussion in much research. Understanding English varieties other than native-speaker norms has been regarded as necessary for effective communication in contexts where English is used as a lingua franca. Numerous academic articles as well as a number of book-length studies on WE have been widely published in international academic journals such as Asian Englishes, English Today, English World-Wide, and World Englishes. Throughout the 1980s, in varied branches of linguistics research and publications, WE has brought a paradigm shift in English studies. WE has shown its important relations with other language studies. In terms of language variation, WE emphasizes the plucientric view of English study or the diversity of English varieties. "Englishes" also symbolizes the functional and formal variation in the language and its international acculturation.

The WE paradigm that has brought together varieties of Englishes [2] has been widely recognised in the past three decades. WE makes three basic claims: 1) there exists a repertoire of models for English, not just the native speaker varieties; 2) localised innovations in English which have their pragmatic bases deserve recognition; and 3) the ownership of English lies with all those who use it[14]. It has recently been interpreted with more comprehensive characterisation with seven characteristics including diversity, plurality, equality, functionality, inclusivity, appropriateness and variability [24]. In [9], it is argued that the global spread of English has generated "multiple norms at the local, national and regional levels" in response to socio-cultural and pragmatic needs of speech communities. These non-native speaker norms are suggested to be equal to native speaker norms and should serve as criteria in judging the appropriateness of English use in Outer Circle contexts [14]. The exploration of these norms as well as teachers' perceptions towards these are thus important in English teaching.

\subsection{Previous studies in Asian context}

In line with the importance of varieties of Englishes in English teaching and learning, much research has been done in Asia to explore the perceptions of English teachers. In some Asian contexts, such as India and Pakistan, new Englishes are widely recognised; while in others, such as Japan, where English is mainly used as a foreign language, the awareness and acceptance of WE are lower. Individual interviews along with student writing were explored in the study. Participants in the study displayed different levels of knowledge about varieties of English, which Suzuki attributed to their prior experiences of social and educational interaction with other second language speakers of English. Nonetheless, only American and British English were regarded as appropriate for English language teaching. The study recommended developing teachers' perceptions of other varieties of English in teacher preparation programs as well as developing skills in teaching English as an international language[28].

The attitudes of Hong Kong's English language teachers in terms of their discourse and their views on correctness or acceptability of Hong Kong English. Over a thousand electronic messages on language issues of English teachers in Hong Kong through a computer network - TeleNex - over a period of two years were analysed. The results showed a preference among Hong Kong's English teachers for Standard English in formal communication rather than Hong Kong English. Nevertheless, the study predicted the change in societal attitudes towards the local variety of English in Hong Kong and towards varieties of Englishes in general given rapid globalisation and the immense impact of the Internet on communication amongst nations[32].

Among several studies in ASEAN contexts, the study investigated the perceptions of teachers, administrators, and students as to the status of Cambodian English, and their preferences for different kinds of English. The recognition of Cambodian English was emphasized in the study in line with the perception of English a second language or international language rather than a foreign language or lingua franca. Although one particular Standard English 
variety was preferred in classroom teaching, others were also drawn on as the context dictated [21].

Despite the increasing importance of WE in English teaching, very few studies have been conducted in Vietnam to explore the kinds of English used or the perceptions of English teachers towards WE. In line with the recognition of WE among many countries within the ASEAN region, it has been argued that Vietnam should develop an understanding of WE to develop and promote "mutual intelligibility" [16]. Nonetheless, the current trend in English language teaching in Vietnam is to privilege British and American standard English. With the participation of 250 students and 80 university teachers from two universities in Vietnam, the study investigated attitudes towards the preferred kinds of English via a mixed-method approach involving questionnaires and interviews. The study found that although students used English more often with non-native speakers, they still preferred studying British and American English. Ton and Pham also suggested that students should explore more English varieties outside the classroom for more effective communication with non-native speakers. The study is presented in the next section will focus on a broader context of Vietnam with more and deeper insights from the teachers' perceptions of WE [29].

\section{METHOD}

The study employed a mixed-methods approach involving both quantitative and qualitative data, which allowed the researcher to explore the breadth and depth of the teachers' perceptions. An online questionnaire was utilised at the first stage with the participation of seventy-six Vietnamese English teachers at university/college level in Vietnam. At the second stage, individual semi-structured interviews and a focus group interview were conducted with five of the Vietnamese English teachers who were pursuing a master's degree in Applied Linguistics at an Australian university. All of these methodological tools were administered in English for the reason all participants were Vietnamese English lecturers at university/college level with good English proficiency. English was also chosen because there are gaps, misunderstandings or difficulties when translating technical terms from English into Vietnamese. The use of English in interviews was thus useful for the participants to express their ideas, although the code-switching was not prohibited.

\section{RESULTS AND DISCUSSION}

The study reported here thus aims to shed light on the perceptions of English teachers at the university / college level in Vietnam towards incorporating WE in their English teaching contexts. The data were collected from a Master thesis of the first author at one university in Australia over six weeks. A mixed-methods approach (involving both quantitative and qualitative data) was employed to answer the research questions. Seventy-six Vietnamese English teachers at the university/college level in Vietnam took part in the first stage of the research, conducted using an online questionnaire (see Table 1). Five of the participants Vietnamese English teachers pursuing a master's degree in Applied Linguistics at an Australian university (see Table 2 ), participated in the interview stage, including individual semi-structured interviews and a focus group interview, after they had answered the online questionnaire. These were all administered in English for the reason that the participants are all Vietnamese English lecturers at university and college level with good English proficiency. English was also chosen because there are gaps, misunderstanding or difficulties when translating technical terms from English into Vietnamese. The use of English in interview is thus useful for the participants to express their ideas, although the code-switching is not prohibited.

In analyzing the data, the first author classified the participants into subgroups according to their teaching major and their previous experiences of WE. Quantitative data were analysed for trends and variance by providing frequencies and percentages. Qualitative data were the major focus of data analysis. Individual and focus group interview data were firstly transcribed and then analysed and interpreted through four stages: reading, coding, sorting, and interpreting. Excerpts from the interview data in the following section are presented in participants' own words, including any non-standard forms and expressions.

In this article, the main findings from the two stages of the study including the online survey and the individual interviews and focus group discussion are presented to grasp a holistic view of the Vietnamese English teachers' perceptions towards WE and introducing WE into their teaching. 
3.1. Online survey

TABLE 1: General description of participants in online questionnaire

\begin{tabular}{|c|c|c|c|c|c|c|c|c|}
\hline 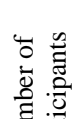 & \multicolumn{2}{|c|}{ Gender } & \multicolumn{5}{|c|}{ Age range } & 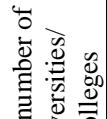 \\
\hline \multirow{2}{*}{$\begin{array}{c}N= \\
76\end{array}$} & 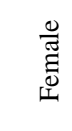 & $\frac{\frac{0}{\pi}}{\sum^{2}}$ & 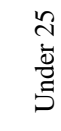 & $\begin{array}{l}\text { क़े } \\
\text { bे }\end{array}$ & $\frac{\stackrel{m}{1}}{m}$ & $\begin{array}{l}\text { q } \\
\text { do } \\
\text { nd }\end{array}$ & $\begin{array}{l}\text { \& } \\
0 \\
0 \\
8 \\
8\end{array}$ & \multirow{2}{*}{26} \\
\hline & $\begin{array}{c}56 \\
(73.7 \\
\%)\end{array}$ & $\begin{array}{c}20 \\
(26.3 \\
\%)\end{array}$ & $\begin{array}{c}2 \\
(2.6 \\
\%)\end{array}$ & $\begin{array}{c}34 \\
(44.7 \\
\%)\end{array}$ & $\begin{array}{c}24 \\
(31.6 \\
\%)\end{array}$ & $\begin{array}{c}5 \\
(6.5 \\
\%)\end{array}$ & $\begin{array}{c}11 \\
(14.5 \\
\%)\end{array}$ & \\
\hline
\end{tabular}

Firstly, the study showed that in terms of the teachers' awareness of English varieties, American and British English were acknowledged by all participants. As for the question exploring the variety of English currently widely used in English teaching in Vietnam, at least $89 \%$ presented American and British English. Given that the answer "Others" constituted $12 \%$, it was considered by the interviewees as "both American and British English". Although the superiority of native varieties such as American or British English was emphasized, non-native varieties such as ASEAN English varieties (i.e. Singaporean English or Hong Kong English) were also recognised by the respondents along with their acceptability of Vietnamese English.

Vietnamese English was widely reported by the participants as an acceptable term along with its features in terms of pronunciation, grammar, and culture, which were noted in reference to differences between Vietnamese and English. Whereas tenses were pointed out as grammatical features of Indonesian English [16], word order ("house big," not "big house") and the use of articles or plural features ("two book," not "two books") were noted by participants as features of Vietnamese English. Vietnamese cultural norms involving direct questions of a personal nature (e.g., related to age, marital status, or financial status) were included as Vietnamese English features, which is to some extent similar to the results of [27] regarding request strategies of Indian English transferred from local languages.
Introducing English varieties in English teaching in Vietnam was also pointed out with both benefits and challenges despite widely being regarded as an important task in English teaching by the participating teachers. Three main benefits of introducing English varieties were shown from the responses. Firstly, it was noted that introducing WE can prepare students for real-life encounters with different varieties of English. It was emphasized by one teacher that "students will be well-prepared for real-life encounters with varieties of English". This was in accordance with another opinion that it helps learners to "expose and get familiar with different varieties of English that are used currently in communication outside classroom". Secondly, introducing English varieties is also considered as beneficial factor for successful communication.

Teaching materials, time and effort consuming and students' reluctance, resistance and confusion as common responses of the challenges of introducing English varieties presented by the participants. Firstly, the teachers claimed that teaching materials are a big problem because "there might be insufficient materials for introducing varieties of English for students", or "lack of proper teaching materials". Secondly, time - and effort - consuming in class was also shown as one issue that needs to be taken into consideration when introducing English varieties. The teachers said that "they have no extra time for introducing these varieties". Teachers' awareness and knowledge of WE or English varieties are also other constraints to Vietnamese English teachers in terms of introducing English varieties.

\subsection{Individual interviews and group discussion}

Further insights of the Vietnamese English teachers' perceptions towards WE and introducing WE into diverse specific teaching contexts were highlighted through individual interviews and a group discussion among the five interviewees as described in Table 2. 
TABLE 2: General description of interviewees

\begin{tabular}{|c|c|c|c|c|c|}
\hline $\begin{array}{l}\text { Name } \\
\text { (pseudonyms) }\end{array}$ & Gender & Age & $\begin{array}{l}\text { City in } \\
\text { Vietnam }\end{array}$ & $\begin{array}{l}\text { English } \\
\text { teaching } \\
\text { major }\end{array}$ & $\begin{array}{l}\text { Semester } \\
\text { in } \\
\text { university }\end{array}$ \\
\hline Manh & Male & 26 & Hanoi & $\begin{array}{l}\text { Major } \\
\text { students }\end{array}$ & $\begin{array}{l}\text { 2nd } \\
\text { semester }\end{array}$ \\
\hline Thanh & Female & 25 & Hue & $\begin{array}{l}\text { Major } \\
\text { students }\end{array}$ & $\begin{array}{l}\text { 3rd } \\
\text { semester }\end{array}$ \\
\hline Suong & Female & 26 & Hanoi & $\begin{array}{l}\text { Major } \\
\text { students }\end{array}$ & $\begin{array}{l}\text { 2nd } \\
\text { semester }\end{array}$ \\
\hline $\mathrm{Tu}$ & Female & 31 & An Giang & $\begin{array}{l}\text { Both } \\
\text { major and } \\
\text { non-major } \\
\text { students }\end{array}$ & $\begin{array}{l}\text { 2nd } \\
\text { semester }\end{array}$ \\
\hline Linh & Male & 28 & Hanoi & $\begin{array}{l}\text { Both } \\
\text { major and } \\
\text { non-major } \\
\text { students }\end{array}$ & $\begin{array}{l}\text { 2nd } \\
\text { semester }\end{array}$ \\
\hline
\end{tabular}

First of all, all of the interviewees agreed that introducing English varieties is important to English teaching. Linh emphasized the importance of introducing English varieties and the suggestion for English learners to understand many English varieties for future encounters.

Suong supported that "The job of teaching is to prepare students for real-life later so if we can prepare them to avoid the shock later when they are exposing with other varieties of English". Manh highlighted the importance of introducing English varieties by mentioning the case of his University as one example. With the aim to reduce students' communication breakdown, a course relating to WE or English varieties is conducted in his university.

However, varied difficulties in divergent teaching contexts were presented when the interviewees mentioned the challenges of introducing English varieties. Of those, teaching and learning materials, time and effort consuming, the selection of suitable varieties, and students and parents ${ }^{\text {ee }}$ resistant attitudes were generally stated as common challenges.

The interviewees also presented varied ideas in line with their different teaching contexts when mentioning their opinions towards their colleagues' attitudes. Suong and Manh noted that their colleagues have a proper understanding of WE as they do. In contrast, Tu posited that her colleagues, like her, do not have knowledge of WE or English varieties "I think that my colleagues have just some general information but not very clear or exactly the term like this." Thanh noted that her colleagues are conservative with native varieties or native-like model and "try to correct the students' pronunciation, intonation to become native speakers.."; whereas, she is more open and focused on more communication and fluency in her teaching.

With a distinct teaching environment from Manh and Suong, Thanh recommended that the change of teachers' attitude and awareness towards English varieties is important. The investment in teacher education, especially teacher study abroad was also emphasised by the interviewees to improve the teachers' knowledge and provide them with opportunities for real communication. $\mathrm{Tu}$ suggested the employment of technology and media as the sources of introducing English varieties to get students familiar with these varieties. The change of the students' awareness, their students' attitude or resistance to English varieties was also recommended. Manh noted that "The teachers should introduce, inspire students with English varieties because students are still more interested in studying native varieties through add-ons components besides native varieties". He asserted that native-like proficiency should not be the target, but intelligibility and comprehensibility.

In the group discussion, when asked to present their opinions towards the statement: "Introducing English varieties, especially non-native varieties, helps students to be confident with their own English and proud of their own English variety", the interviewees presented different points of view. Manh agreed with this idea and posited that accent is not really important. He emphasized the importance of students' tolerant attitude with different accents, which was also supported by Thanh. She clarified that "In my teaching, I focus on more communication, fluency and a bit on accuracy, the accent needs to be accepted to identify identity...". Linh added the positive prospect that the students' Vietnamese accent and Vietnamese variety of English might be accepted around the world. Despite having rapport on this statement, Suong took more caution with the word "confidence". She showed her hesitance: “...That kind of confidence should be taken with caution. It may mislead students into believing that they do not need improvement..." However, they all showed an appropriate attitude towards English varieties, whether they are native or non-native varieties.

The second statement aims to present a discussion of the issue of native-like competence as the main goal of teaching, which deduces the un-necessity of introducing English varieties into teaching. Manh presented his disagreement by noting that, "native-like is most of the time not the target of 
learning English but the effectiveness on communication". This was agreed by the other interviewees. Regarding the students' confusion, Linh said that "they might be confused at the first stage", but for him, "that's not important issue". Tu suggested the level of students should be taken into investigation when introducing English varieties to reduce students' confusion.

The third issue related to the exam-oriented purposes of teaching and learning English in Vietnam, which might lead to an emphasis on teaching British and American English only. Discussing this point, all interviewees emphasized the necessity of an analysis of students' needs to identify the students' purposes of learning English and choose suitable teaching content and method. They also put an emphasis on the necessity of English varieties on real life communication or encounters of different English varieties. They claimed that introducing English varieties does not aim to change the learners' goals or targets (exam-oriented) but their awareness and attitudes towards English varieties. Manh added that "No matter how hard we try, we cannot reach the target (Standard English)". Therefore, he suggested the teachers let the students aim for their targets, but still introduce English varieties to help students better with real-life encounters and communication. "We still focus on those targets, but at the same time, we can change students' awareness, attitude towards remarkable English varieties (through introducing English varieties)...”.

Overall, through individual interviews and a group discussion among the five focused participants, their perceptions of WE as well as detailed suggestions towards introducing WE into their teaching in line with their working conditions were uncovered. The next section will discuss further considerations in relation to English education in Vietnam.

Firstly, as the findings delineated in the previous section, with regard to introducing varieties of English, different teaching contexts revealed diverse perceived advantages and challenges. Therefore, to develop a suitable approach to their introduction, teachers must carefully consider each teaching context to employ appropriate actions in teaching or "clear and consistent learning models" [29]

In universities with support for teaching WE, Englishes were recommended to be introduced through task-based language teaching. This approach may afford students the autonomy to select which varieties of English they may want to explore. Tasks related to real-life situations might also intrigue and stimulate students with the exploration and understanding of different kinds of English[19]. In universities or colleges with no courses relating to WE, these tasks was suggested to be attached to other courses such as intercultural communication or listening subjects. In these certain circumstances, teachers could also use postcards, YouTube videos, or intercultural movies to introduce different Englishes.

Regarding teachers' knowledge and awareness, changing teachers' conservative attitudes towards other Englishes, including non-native varieties, was also regarded as an important task. Holding workshops, teachers' meetings, and discussions about WE were also recommended. The participants in this study focused more on investment in overseas teacher training such as that provided by the Vietnamese Ministry of Education and Training. Through their experiences overseas with issues related to other kinds of English, participants noted that they believed that overseas training provides English teachers with real-life experiences to improve their awareness of teaching issues in international contexts.

Besides these above discussed points, other aspects need to be taken into consideration in English education in Vietnam. First, there is a need to provide teacher training to improve teachers' knowledge and awareness. English teachers should also have opportunities to involve themselves in real-life English communication via funded short-term or long-term overseas courses. Further discussions or workshops should also be held to reach a consensus among teachers regarding the best methods for including WE in specific contexts.

In addition, teaching materials including textbooks and curriculum should be taken into investigation for better teaching and learning outcomes. Therefore, on the one hand, teaching materials should cover the interest and perceptions of English teachers, on the other hand, they should be varied so that teachers and learners can expose to different varieties. From these, students can also choose their own varieties which they aim to explore in details.

In the case of Vietnam, the current study showed that $\mathrm{WE}$ is still new and teaching WE is still an individual teacher choice. In line with the development of WE in English teaching context in Vietnam, further critical questions will be raised that teachers and educational developers might face, such as the question of how TESOL teachers distinguish between errors in the SLA sense and 
varietal features in the WE sense [8]. As it is claimed that, failure to draw clear boundaries between errors and nurture innovations may have academic and social consequences [13]. In other words, since teachers are already involved in process of judging English as part of their practice, it is important to investigate the processes and criteria for distinguishing between errors and innovations from their perspectives. These issues are still remained to be addressed and answered in the context of English teaching in Vietnam not only at individual teacher level but must be at a larger scope of researching.

In accordance with the perceptions of teachers toward WE in the context of Vietnam, in addition to discussions in the field in relation to errors and norms, the development of English in specialised area such as Journalisam or Business English needs to take into consideration. It is undeniable that English communications among ASEAN countries, especially after the resolutions of the ASEAN Economic Community, is mainly conducted in the field of business. Therefore, how to teach as well as what or which varieties to be included in Business English in line with the development of different Englishes from other countries of the region or just Standard English are unavoidable questions. Indeed, how to equip students with the understanding and exposure to these Englishes should thus be addressed for further considerations by educators.

Combined with these concerns, policy makers and educators should exercise care in finding suitable approaches for teachers' development, teaching materials and testing and assessment tools. Choosing a suitable assessment tool is one of the important tasks that policy makers and educators need to be considered. In fact, besides the international tests widely employed in English teaching and learning in Vietnam such as IELTS or TOEFL, the Vietnamese Standardised Test of English Proficiency (VSTEP) has been constructed and put into effect since 2015. One of the aim of this test to construct an assessment tool which is more appropriate with Vietnamese English users. In terms of listening, for instance, this assessment tool covers different listening topics close to the context of Vietnamese and non-native speakers perspectives. Rather than testing native speaking ability of native accent, it is noted in the training documents of writing test items for VSTEP that the ability to listen to talks or conversations by different accents such as Singaporean English or Indian English were noted as a feature of this assessment tool. However, how to clarify the test aims to teachers and students, or launch and develop more of this kind of test to the public still need more work from the policy makers at a grass-root level.

\section{CONCLUSION}

The study reported here explored Vietnamese English teachers' perceptions of World Englishes as well as their beliefs regarding their introduction. Perceptions, suggestions, and imagined actions of the study's participants provide insights into the current experience of teachers who work in contexts where the variety of English taught is not necessarily representative of the varieties that students may be exposed to living and working in the ASEAN region. The research also adds to the limited amount of literature on WE in Vietnam, and provides evidence of the potential influence of WE in English language education in a region which is becoming increasingly interconnected and where competence in different kinds of English is destined to become necessary for successful intercultural communication.

Further research thus needs to be conducted over a longer period to grasp the breadth of views expressed. More work is needed into the analysis of Vietnamese English features to provide researchers, teachers, and learners with a clear understanding of what makes this variety of English unique. Finally, there has been inadequate research on teachers' judgments of L2 use from the SLA-WE contrastive perspectives. Questions need to be raised in terms of whether there is a consensus among teachers in their understandings of errors and varietal features; what criteria they use in judging the status of L2 features; and whether these criteria are different from those suggested in the literature.

\section{REFERENCES}

[1] Brutt-Griffler, J. (2002). World English. A study of its development. Clevedon: Multilingual Matters.

[2] Bolton, K. (2004). World Englishes. In A. Davies \& C. Elder (Eds.), The handbook of applied linguistics (pp. 367-420). Oxford: Blackwell.

[3] Canagarajah, A. S. (2006). Negotiating the local in English as a Lingua Franca. Annual Review of Applied Linguistics, 26, 197-218.

[4] Chan, S. H. \& Wong, B. E. (2002). The Malaysian English language competency dilemma: Recovering lost grounds through MUET. Journal of Pan-Pacific Association of Applied Linguistics, 6(1), $31-42$. 
[6] Cook, V. J. (2002). Portraits of the L2 user. Clevedon: Multilingual Matters.

[7] Crismore, A., Yeok-Hwa, K., \& Keng-Soon, S. (1996). Attitudes towards English in Malaysia. World Englishes, 15(3), 319-335.

[8] Hamid, O. (2014). World Englishes in international proficiency tests. World Englishes, 33(2), 263-277.

[9] Hamid, O., Zhu, L, \& Baldauf, J.R. (2014). Norms and varieties of English and TESOL teacher agency. Australian Journal of Teacher Education, 39(10), 76-95

[10] Holliday, A, R. (2005). The struggle to teach English as an international language. Oxford: Oxford University Press.

[11] Honna, N. (1999). Ajia wo Tsunagu Eigo [English Unifying Asia]. Tokyo: ALC

[12] Ho Wah Kam \& Wong, R. (2003). English language teaching in East Asia Today. Singapore: Eastern University Press.

[13] Hsu, H. L. (2012). The impact of world Englishes on language assessment: Rater attitude,

rating behavior, and challenges. Unpublished $\mathrm{PhD}$ thesis. UrbanaChampaign: University of Illinois at Urbana-Champaign.

[14] Kachru, Braj B. (1988). Teaching World Englishes. ERIC/CLL News Bulletin, 12(1).1, 3, 4, 8 .

[15] Kirkpatrick, A. (2002). ASEAN and Asian cultures and models: Implications for the ELT curriculum and teacher selection. In A. Kirkpatrick (Ed.), Englishes in Asia: Communication, identity, power and education (pp. 213-224). Melbourne, Australia: Language Australia.

[16] Kirkpatrick, A. (2007). World Englishes: Implications for international communication and English language teaching. New York: Cambridge University Press.

[17] Kirkpatrick, A. (2008). English as the official working language of the Association of Southeast Asian Nations (ASEAN): Features and strategies. English Today, 24(2), 27-34. http://dx.doi.org/10.1017/S0266078408000175

[18] Kirkpatrick, A. \& Bhatt, R. M. (2010). World Englishes. The study of new linguistic varieties. World Englishes, 29(1), 138-141.

[19] Matsuda, A. (2003). Incorporating World Englishes in teaching English as an international language. TESOL Quarterly, 37(4). http://dx.doi.org/10.2307/3588220

[20] Melchers, G. \& Shaw, P. (2003). World Englishes. London: Arnold.

[21] Moore, S. H. \& Bounchan, S. (2010). English in Cambodia: changes and challenges. World Englishes, 29(1), 114-126.

[22] O'Hara-Davies, B. (2010). Brunei English: A developing variety. World Englishes, 29(3), 406-419.

[23] Prodromou, L. 1997. 'Global English and the Octopus'. IATEFL Newsletter, 137, 18-22.

[24] Proshina, Z. G. (2012). Language Revolution behind the curtain. Paper presented at the 18 th

International Conference of the International Association of World Englishes. The
University of Hong Kong, Hong Kong.

[26] Sewell, A. (2013). English as a lingua franca: Ontology and ideology. ELT Journal, 67(1), 3-10. http://dx.doi.org/10.1093/elt/ccs061

[27] Sridhar, K. K. (1991). Speech Acts in An Indigenized Variety: Sociocultural Values And

Language Variation, In Jenny Cheshire ed. English Around the World, Cambridge: Cambridge University Press.

[28] Suzuki, A. (2011). Introducing diversity of English into ELT: Student teachers' responses. ELT Journal, 65(2), 146-153.

[29] Swan, M. (2012). ELF and EFL: Are they really different? Journal of English as a Lingua Franca, 1(2), 379-389. http://dx.doi.org/10.1515/jelf-2012-0025

[30] Tananuraksakul, N. (2009). Unintelligibility : world Englishes shock and repetition shock in an Australian context. Prospect, 24(2), 4252.

[31] Ton, H. \& Pham, H. (2010). Vietnamese teachers' and students' perceptions of Global English. Language Education in Asia, 1, 4861.

[32] Tsui, A. B. M. \& Bunton, D. (2000). The discourse and attitudes of English language teachers in Hong Kong. World Englishes, 19(3), 287-303. 